\title{
EVALUASI SISTEM AKUNTANSI PENJUALAN KREDIT, PIUTANG DAN PENERIMAAN KAS PADA PT. INSAN MEDIA PRATAMA
}

\author{
Vini Mariani; Sintha Permatasari \\ Jurusan Sistem Informasi, Fakultas Ilmu Komputer, Binus University \\ Jl. KH. Syahdan No. 9, Palmerah, Jakarta Barat 11480. \\ vmariani@binus.edu
}

\begin{abstract}
Credit sales in a company have greater risks than cash sales do. An excellent internal control is needed over the accounting system of credit sales, receivables and cash receipts to reduce the occurrence of these risks. This study aims to evaluate, identify weaknesses and limitations of internal control and suggests some improvements as needed. The methods used are literary study on books, textbook, and other related literatures; field research by interviewing the relevant parts and observing the company activities, forms and accounting records used.
\end{abstract}

Keywords: evaluation, accounting system, credit sales, receivable.

\begin{abstract}
ABSTRAK
Penjualan secara kredit pada suatu perusahaan memiliki resiko yang lebih besar dibandingkan penjualan tuna. Diperlukan suatu pengendalian internal yang baik atas sistem akuntansi penjualan kredit, piutang dan penerimaan kas untuk mengurangi terjadinya resiko tersebut. Penelitian ini bertujuan untuk mengevaluasi, mengidentifikasi kelemahan dan keterbatasan dari pengendalian intern serta memberikan saran perbaikan yang diperlukan. Metode yang digunakan meliputi studi kepustakaan buku-buku, diktat, dan literatur yang berkaitan serta penelitian lapangan dengan cara wawancara kepada bagian-bagian yang terkait dan observasi terhadap kegiatan perusahaan, formulir serta catatan akuntansi yang digunakan perusahaan.
\end{abstract}

Kata kunci: evaluasi, sistem akuntansi, penjualan kredit, piutang, penerimaan kas. 


\section{PENDAHULUAN}

\section{Latar Belakang Penelitian}

Penjualan kredit dan piutang merupakan dua hal yang tidak dapat dipisahkan, karena penjualan kredit akan selalu menimbulkan piutang. Tidak ada atau lemahnya pengendalian internal dalam sistem akuntansi penerimaan kas akan berakibat semakin besarnya resiko kerugian yang akan ditanggung perusahaan akibat tak tertagihnya piutang maupun penyimpangan atau kecurangan akan yang mengakibatkan terancamnya kelangsungan hidup perusahaan. Untuk itu diperlukan adanya pengendalian intern yang baik untuk mendukung sistem akuntansi ketiganya.

Sistem akuntansi penjualan tunai maupun kredit dan penerimaan kas yang efektif dan efisien akan sangat mendukung strategi perusahaan untuk mencapat tingkat laba yang maksimal. Perusahaan dapat menjalankan kegiatan operasinya dengan baik juka didukung dengan sistem akuntansi yang sesuai dengan kondisi dan kebutuhan perusahaan.

PT. Insan Media Pratama merupakan perusahaan yang bergerak dalam bidang jasa informasi media cetak yang berlokasi di Jalan Mede No. 42, Jakarta Timur, yang menaungi 2 majalah Islam nasional, yaitu Majalah Ummi dan Majalah Annida. Customer-nya terdiri dari agen, pembeli yang berlangganan secara rutin, serta pembeli lepas (tidak berlangganan). Perusahaan ini jugal melayani usaha kecil yang berminat menjadi agen Majalah Ummi dan Majalah Annida di kota kecil. Dengan bertambahnya agen yang tersebar di berbagai kota di Indonesia, perlu adanya penerapan sistem akutnansi dan pengendalian intern yang tepat dan sesuai untuk mencegak terjadinya resiko piutang tak tertagih dan penyimpangan atau kecurangan yang akan mengakibatkan terancamnya kelangsungan hidup perusahaan.

Berdasarkan penjelasan di atas, dapat kita ketahui bahwa sistem akuntansi penjualan kredit dan piutang serta sistem akuntansi penerimaan kas memiliki perananan yang sangat penting bagi perusahaan khususnya dalam pencapaian tujuan pengendalian intern perusahaan. Oleh karena itu penulis tertarik memilih topik "Evaluasi Sistem Akuntansi Penjualan Kredit, Piutang dan Penerimaan Kas Pada PT. Insan Media Pratama”.

\section{Ruang Lingkup Penelitian}

Penelitian ini dibatasi hanya pada: (1) Fungsi-fungsi yang terkait dalam sistem akuntansi penjualan kredit, piutang dan penerimaan kas; (2) Dokumentasi dan catatan akuntansi yang digunakan dalam sistem akuntansi penjualan kredit, piutang dan penerimaan kas; (3) Pengendalian intern yang diterapkan dalam sistem akuntansi penjualan kredit, piutang dan penerimaan kas; (4) Dalam melakukan evalausi sistem akuntansi penjualan kredit dan piutang, penulis membatasi pembahasan masalah hanya pada penjualan kredit untuk Majalah Ummi kepada agen dan tidak membahas pajak; (5) Dalam melakukan evaluasi sistem akuntansi penerimaan kas, penulis membatasi pembahasan masalah hanya pada penerimaan kas dari piutang.

\section{Tujuan dan Manfaat Penelitian}

Tujuan dari penelitian ini adalah: (1) Menganalisis kelemahan dari prosedur sistem akuntansi penjualan kredit, piutang dan penerimaan kas yang sedang berjalan; (2) Mengevaluasi kelemahan dari prosedur sistem akuntansi penjualan kredit, piutang dan penerimaan kas, serta keterbatasan dari pengendalian intern yang diterapkan perusahaan; (3) Memberi rekomendasi mengenai prosedur akuntansi penjaulan kredit, piutang dan penerimaan kas yang sebaiknya diterapkan perusahaan; 
Sedangkan manfaat yang dapat diperoleh dari penelitian ini adalah: (1) Memberi gambaran tentang sistem akuntansi penjualan kredit, piutang dan penerimaan kas yang diterapkan oleh perusahaan; (2) Mengevaluasi kebaikan dan kelamahan pada prosedur dan sistem akuntansi penjualan kredit, piutang dan penerimaan kas yang diterapkan oleh perusahaan dan sebagai bahan pertimbangan bagi pihak manajemen untuk memperbaiki kelemahan, serta mendorong tercapainya suatu pengendalian intern yang efektif bagi perusahaan; (3) Diharapkan dari rekomendasi yang diusulkan, dapat meningkatkan efisiensi dalam prosedur penjualan kredit, piutang dan penerimaan kas perusahaan.

\section{Landasan Teori}

\section{Sistem Akuntansi}

Menurut Mulyadi (2001, p.5), "Sistem adalah suatu jaringan prosedur yang dibuat menurut pola yang terpadu untuk melaksanakan kegiatan pokok perusahaan”.

Menurut James A. Hall yang diterjemahkan oleh Fitriasari, D dan Kwary, D.A (2007, p.6) dalam bukunya menyatakan, "Sistem adalah kelompok dua atau lebih komponen atau subsistem yang saling berhubungan yang berfungsi dengan tujuan yang sama”.

Berdasarkan pengertian di atas, dapat disimpulkan bahwa sistem adalah sekelompok unsur yang satu sama lainnya berhubungan erat, yang bersatu untuk mencapai tujuan tertentu.

Menurut C.T., Harrison Jr, W.T., dan Bamber, L.S. (2002:5) menjelaskan bahwa “Accounting is the information system that measures business activities processes that information into reports, and communicates the results to decision makers".

Menurut Reeve, Warren, Duchac, Wahyuni E.T., Soepriyanto, G., Jusuf, A.A. (2008, p.7) "Accounting can be defined as an information system that provide reports to stakeholders about the economic activities and condition of a business”.

Berdasarkan pengertian di atas, dapat disimpulkan bahwa akuntansi adalah proses pengidentifikasian, pengukuran, pencatatan, pengklasifikasian, penguraian, penggabungan, peringkasan dan penyajian informasi keuangan untuk kepentingan para pemegang saham.

Menurut Mulyadi (2001, p.3), "Sistem akuntansi adalah organisasi formulir, catatan, dan laporan yang dikoordinasikan sedemikian rupa untuk menyediakan informasi keuangan yang dibutuhkan oleh manajemen guna memudahkan pengelolaan perusahaan”.

Menurut Warren, Reeve, dan Fess yang diterjemahkan oleh Farahmita A, Amanugrahani, dan Hendrawan, T (2005, p.226), "Sistem akuntansi adalah metode dan prosedur untuk mengumpulkan, mengklasifikasikan, mengikhtiarkan, dan melaporkan informasi operasi dan keuangan sebuah perusahaan".

Dari pengertian di atas, dapat disimpulkan bahwa dalam sistem akuntansi terdapat beberapa aktivitas, diantaranya mengidentifikasi, mengumpulkan, mengklasifikasi, menganalisis, mencatat dan melaporkan informasi keuangan yang dibutuhkan manajemen untuk memudahkan pengelolaan perusahaan. Unsur sistem akuntansi berupa: (1) formulir, (2) jurnal, (3) buku besar, (4) buku pembantu, (5) laporan.

\section{Sistem Pengendalian Internal}

Menurut Mulyadi (2001, p.163), "Sistem Pengendalian Internal meliputi struktur organisasi, metode dan ukuran-ukuran yang dikoordinasikan untuk menjaga kekayaan organisasi, mengecek 
ketelitian dan keandalan data akuntansi, mendorong efisiensi dan mendorong dipatuhinya kebijakan manajemen”.

Sedangkan menurut Bodnar, G.H. dan Hopwood, W.S. yang diterjemahkan oleh Saputra J.A dan Setiawati, L. (2006, p.11), "Pengendalian internal merupakan satu proses yang dirancang untuk menyediakan keyakinan yang rasional atas tercapainya tujuan reliabilitas pelaporan keuangan, efektivitas dan efisiensi operasi perusahaan, kesesuaian organisasi dengan aturan serta regulasi yang ada”.

Berdasarkan pengertian di atas, dapat disimpulkan bahwa system pengendalian internalal adalah proses yang dirancang meliputi struktur organisasi, metode dan ukuran-ukuran yang dikoordinasikan untuk tercapainya tujuan perusahaan dalam menjaga kekayaan, menjaga efektivitas dan efisiensi operasi, serta dipatuhinya atuaran serta regulasi yang menjadi kebijakan manajemen.

Unsur pokok sistem pengendalian internal dalam perusahan adalah: (1) struktur organisasi yang memisahkan tanggung jawab fungsional secara tegas; (2) sistem wewenang dan prosedur pencatatan yang memberikan perlindungan yang cukup terhadap kekayaan, utang, pendapatan dan biaya; (3) praktik yang sehat dalam melaksanakan tugas dan fungsi setiap unit organisasi; (4) karyawan yang mutunya sesuai dengan tanggung jawabnya.

Menurut Bodnar dan Hopwood (2000, p.195), terdapat unsur pengendalian internal lain yang harus ada yaitu: (1) Pengendalian Preventif - dilakukan untuk mencegah kekeliruan dan penipuan sebelum keduanya terjadi, terutama pada tahap masukan dan pemrosesan pada pemrosesan transaksi; (2) Pengendalian Detektif - dilakukan untuk mengatasi kekeliruan dan penipuan setelah keduanya terjadi; (3) Pengendalian Korektif - digunakan untuk mengoreksi kekeliruan.

\section{Sistem Akuntansi Penjualan Kredit}

Pengertian Penjualan Kredit menurut Wibowo dan Arif, A (2002, p.87), "Penjualan kredit adalah penjualan barang dagangan dengan kesepakatan antara pembeli dan penjual pada saat transaksi, yaitu dengan pembayaran akan dilakukan pada waktu yang akan datang”. Pengertian piutang menurut Warren, Reeve dan Fess yang diterjemahkan oleh Farahmita, A., Amanugrahani, dan Hendrawan, T (2005, p.392) adalah "Istilah piutang meliputi semua klaim dalam bentuk uang terhadap pihak lainnya, termasuk individu, perusahaan atau organisasi lainnya. Piutang biasanya memiliki bagian yang signifikan dari total aktiva lancer perusahaan. Traksasi paling umum yang menciptakan piutang adalah penjualan barang dagang atau jasa secara kredit. Iutang usaha semacam ini normalnya diperkirakan akan tertagih dalam periode waktu yang relative pendek, seperti 30 atau 60 hari”. Menurut Wibowo dan Arif, A (2002, p.149), "Piutang mengandung pengertian klaim terhadap sejumlah uang yang diharapkan akan diperoleh pada masa yang akan datang”. Berdasarkan ketiga pengertian tersebut, dapat disimpulkan bahwa piutang adalah semua klaim dalam bentuk uang yang terhadap pihak lain yang diharapkan akan diperoleh pada masa yang akan datang.

Pengertian retur penjualan menurut Stice, E.K., Stice, J.D., dan Skousen, K.F. (2010, p.327) adalah "In the normal course of business, some goods will be returned by customers and some allowance will have to be made for factors such as goods demaged during shipment, spoiled or otherwise defective goods, or shipment of an incorrect quantity or type of goods". Sedangkan dalam bukunya Larson, K.D., Wild, J.J., dan Ciappetta, B. (2002, p.225), menjelaskan "Sales returns refer to merchandise that customers return to the seller after a sale". Berdasarkan pengertian di atas, dapat disimpulkan bahwa retur penjualan adalah kegiatan pengembalian barang oleh pelanggan dikarenakan beberapa factor, seperti barang yang diterima tidak sesuai dnegan yang dipesan, barang rusak selama perjalanan atau kualitas yang kurang bagus. 
Sistem penerimaan kas dari piutang harus menjamin diterimanya kas dari debitur oleh perusahaan, bukan oleh karyawan yang tidak berhak menerimanya. Untuk menjamin diterimanya kas oleh perusahaan, system penerimaan kas dari piutang mengharuskan debitur melakukan pembayaran dengan cek atau dengan cara pemindahbukuan melakui rekening bank, dan kas yang diterima dalam bentuk cek dari debitur harus segera disetor ke bank dalam jumlah penuh. Penerimaan kas dari piutang dapat dilakukan melalui berbagai cara seperti melalui Penagih Perusahaan, Pos, Lock-Box-Collection Plan (Mulyadi, 2001). Menurut Mulyadi (2001), fungsi yang terkait dalam sistem penjualan kredit adalah fungsi penjualan, fungsi kredit, fungsi gudang, fungsi pengiriman, fungsi penagihan, dan fungsi akuntansi.

Prosedur penjualan kredit terdiri dari prosedur order penjualan, prosedur persetujuan kredit, prosedur pengiriman, prosedur penagihan, prosedur pencatatan piutang, prosedur distribusi penjualan, dan prosedur pencatatan harga pokok penjualan. Dokumen akuntansi yang digunakan terdiri dari surat order pengiriman (dan tembusannya), faktur penjualan, bukti kas masuk, memo kredit, rekapitulasi harga pokok penjualan, dan bukti memorial.

Catatan akuntansi yang digunakan terdiri dari Jurnal Penjualan, Jurnal Retur Penjualan, Jurnal Penerimaan Kas, kartu piutang, kartu persediaan, kartu gudang, dan Jurnal Umum. Standard kredit digunakan oleh banyak perusahaan untuk memutuskan pelanggan mana yang pantas mendapat kredit dan seberapa besar kredit yang dapat mereka terima, di antaranya karakter, kapasitas, kapital, kolateral, dan kondisi. Penentuan standar kredit mengharuskan perusahaan untuk menilai kredibilitas pelanggan.

\section{METODE}

Dalam rangka memperoleh data yang relevan dengan masalah yang akan dibahas, penulis mengadakan serangkaian penelitian dengan menggunakan beberapa teknik pengumpulan data sebagai berikut: (1) Penelitian kepustakaan - metode pengumpulan data yang diperoleh dari sumber-sumber kepustakaan dengan membaca dan mempelajari buku, literatur, dan sumber data lainnya yang berhubungan dengan masalah yang sedang diteliti; (2) Penelitian Lapangan - pengumpulan data dan gambaran yang nyata, dengan mengunjungi dan meninjau secara langsung ke lapangan, yaitu dengan

cara: (a) Pengamatan - mengadakan pengamatan fisik dan meninjau kegiatan perusahaan secara langsung untuk memperoleh gambaran nyata yang berhubungan dengan permasalahan yang diteliti; (b) Wawancara - mengadakan tanya jawab secara langsung kepada pihak yang berwenang yan mengetahui tentang objek permasalahan yang dibahas oleh penulis guna memperoleh informasi yang lebih jelas dan akurat; (c) Dokumentasi - melakukan pengumpulan data dan informasi yang dibutuhkan dan dokumen dan catatan administrasi perusahaan; (d) Prosedur Analisis - metode pengumpulan informasi dengan menganalisis data yang diperoleh dari narasumber. Kesimpulan dari analisis tersebut akan menjadi sumber informasi.

\section{HASIL DAN PEMBAHASAN}

Dari hasil evaluasi ditemukan beberapa jenis dokumen yang digunakan dalam prosedur penjualan kredit, retur penjualan dan penerimaan kas secara umum memiliki beberapa kelebihan antara lain: (1) Rancangan formulir sederhana dan mudah dimengerti, sehingga dapat meminimalisasi terjadinya kesalahaan dalam pengisian formulir; (2) Perusahaan sudah memanfaatkan tembusan atau copy formulir; (3) Perusahaan telah mencantumkan nama dan alamat perusahaan pada setiap formulir, terutama yang digunakan untuk komunikasi dengan agen, sehingga dapat memudahkan identifikasi 
asal formulir tersebut bagi agen; (4) Perusahaan telah menggunakan Bukti Retur sebagai pengganti Memo Kredit. Selain kelebihan di atas, terdapat juga enam kelemahan dari dokumen-dokumen yang digunakan (Tabel 1-6).

Tabel 1

Kelemahan pada Dokumen (1)

\begin{tabular}{ll}
\hline Kondisi & Formulir belum menggunakan nomor urut tercetak \\
\hline Kriteria & $\begin{array}{l}\text { Salah satu prinsip dasar perancangan formulir adalah pencantuman nomor urut tercetak. Nomor } \\
\text { urut tercetak digunakan untuk: (1) mengawasi pemakaian formulir; (2) Mengidentifikasi } \\
\text { transaksi bisnis; (3) Memudahkan pencarian kembali saat dokumen tersebut dibutuhkan. }\end{array}$ \\
\hline Sebab & $\begin{array}{l}\text { (1) Perusahaan menganggap belum membutuhkan karena tidak efektif apabila terjadi kesalahan } \\
\text { dalam pengisian formulir; (2) Akan membutuhkan biaya tambahan untuk mencetak } \\
\text { formulir baru }\end{array}$ \\
\hline Akibat & (1) $\begin{array}{l}\text { Tidak ada pengawasan dalam penggunaan formulir sehingga pertanggungjawaban atas } \\
\text { jumlah transaksi menjadi sulit; (2) Kesulitan dalam mengidentifikasi transaksi bisnis dan }\end{array}$ \\
& $\begin{array}{l}\text { pencocokan informasi antara dokumen yang saling berhubungan; (3) Kesulitan dalam } \\
\text { melakukan pengarsiapan dan pencarian kembali dokumen tersebut apabila suatu saat } \\
\text { dibutuhkan; (4) Gagalnya unsur pengendalian preventif. }\end{array}$ \\
\hline Rekomendasi & $\begin{array}{l}\text { Memodifikasi format formulir dengan menambahkan nomor urut tercetak sehingga dapat } \\
\text { melakukan pengawasan dalam penggunaannya dan untuk menghindari kesalahan dalam } \\
\text { pengidentifikasian informasi serta memudahkan pengarsipan dan pencarian kembali saat } \\
\text { dokumen dibutuhkan. }\end{array}$ \\
\hline
\end{tabular}

Tabel 2

Kelemahan pada Dokumen (2)

\begin{tabular}{ll}
\hline Kondisi & $\begin{array}{l}\text { Formulir tidak mencantumkan kode agen, harga satuan dan total, kolom otorisasi, tanggal jatuh } \\
\text { tempo, nomor dan tanggal formulir. }\end{array}$ \\
\hline Kriteria & $\begin{array}{l}\text { Setiap formulir harus dirancang sedemikian rupa agar dapat bermanfaat untuk: (1) Menetapkan } \\
\text { tanggung jawab timbulnya transaksi transaksi bisnis perusahaan; (2) Merekam data transaksi } \\
\text { bisnis perusahaan; (3) Mengurangi kemungkinaan kesalahan dengan cara menyatakan semua } \\
\text { kejadian dalam bentuk tulisan; (4) Menyampaikan informasi pokok dari orang satu ke orang lain } \\
\text { dalam organisasi sama atau ke organisasi lain. }\end{array}$ \\
\hline Sebab & $\begin{array}{l}\text { Perusahaan telah menggunakan desain formulir tersebut sejak berdiri dan belum sempat } \\
\text { memperbaikinya karena mengganggap belum terlalu memerlukan desain formulir yang baru. }\end{array}$ \\
\hline Akibat & Gagalnya unsur pengendalian korektif dan beberapa hal lainnya. \\
\hline Rekomendasi & $\begin{array}{l}\text { Memodifikasi beberapa format formulir tersebut dengan menambahkan beberapa informasi } \\
\text { dalam masing-masing formulir agar dapat memudahkan identifikasi dan menghindari kesalahan } \\
\text { dalam pengisian serta penggunaan formulir. }\end{array}$ \\
\hline
\end{tabular}

Tabel 3

Kelemahan pada Dokumen (3)

\begin{tabular}{ll}
\hline Kondisi & Tidak terdapat Surat Jalan. \\
\hline Kriteria & Surat Jalan merupakan dokumen yang berfungsi sebagai surat pengantar atas barang yang \\
& tercantum di dalamnya yang ditujukan kepada customer atau penerima yang ditentukan oleh \\
& pembeli dan mempunyai kekuatan hukum atas legalitas yang diperlukan di jalan raya, mulai dari \\
& keluar perusahaan sampai memasuki wilayah milik customer sehingga barang dengan quantity, \\
& spesifikasi yang disertai dengan informasi lainnya diterima oleh customer. Umumnya jumlah \\
& copy atau tembusan yang diperlukan tiga lembar. \\
\hline Sebab & $\begin{array}{l}\text { Perusahaan menggangap informasi yang terdapat dalam faktur penjualan sudah cukup } \\
\text { mewakili sebagai surat jalan untuk fungsi pengiriman sebagai dokumen yang menyertai } \\
\text { pengiriman pesanana majalah kepada agen. }\end{array}$ \\
\hline Akibat & (1) Pengendalian internal terhadap jasa pengiriman khususnya untuk pesanan majalah oleh \\
& agen yang berada di luar kota menjadi kurang maksimal.; (2) Gagalnya unsur pengendalian \\
\hline
\end{tabular}


preventif; (3) Terjadinya kelalaian oleh jasa pengiriman; (4) Apabila terjadi kerusakan selama dalam perjalanan, jasa pengiriman tidak akan bertanggung jawab karena tidak terdapat dokumen yang mempunyai kekuatan hukum atas legalitas yang diperlukan di jalan raya.

Rekomendasi Membuat surat jalan untuk memaksimalkan pengendalian terhadap jasa pengiriman agar melakukan tugas sesuai dengan tanggung jawabnya.

Tabel 4

Kelemahan pada Dokumen (4)

\begin{tabular}{ll}
\hline Kondisi & Tidak terdapat bukti pengeluaran barang. \\
\hline Kriteria & $\begin{array}{l}\text { Seharusnya perusahaan memiliki bukti pengeluaran barang yang dibuat oleh fungsi gudang yang } \\
\text { menerangkan bahwa fungsi gudang telah menyiapkan dan mengeluarkan barang sesuai dengan } \\
\text { jenis dan kuantitas barang yang diminta dan telah menyerahkannya ke fungsi pengiriman dengan } \\
\text { menyertakan dokumen tersebut di dalamnya. }\end{array}$ \\
\hline Sebab & $\begin{array}{l}\text { (1) Perusahaan menganggap informasi yang terdapat dalam faktur penjualan dan rekapitulasi } \\
\text { surat order sudah cukup untuk menyiapkan dan mengeluarkan barang dari fungsi gudang; } \\
\text { (2) Belum terdapat prosedur yang mengatur tentang pentingnya dokumen tersebut. }\end{array}$ \\
\hline Akibat & $\begin{array}{l}\text { (1) Jika fungsi pengiriman merasa tidak menerima barang atau barang hilang dicuri, fungsi } \\
\text { gudang akan sulit membuktikan bahwa barang telah diserahkan; (2) Gagalnya unsur } \\
\text { pengendalian korektif. }\end{array}$ \\
\hline $\begin{array}{l}\text { Membuat Bukti Pengeluaran Barna, selain untuk memastikan jumlah yang diserahkan adalah } \\
\text { sesuai dengan permintaan, dokumen ini juga mengontrol jumlah pengeluaran barang dari } \\
\text { gudang. Bukti pengeluaran barang minimal memuat informasi mengenai nama majalah, edisi } \\
\text { majalah, nomor surat order, jumlah permintaan, jumlah yang diserahkan, sisa stok, dan } \\
\text { keterangan atau catatan. Dokumen ini juga harus ditanda tangani oleh pembuat yaitu fungsi } \\
\text { gudang, penerima yaitu fungsi pengiriman. }\end{array}$
\end{tabular}

Tabel 5

Kelemahan pada Dokumen (5)

\begin{tabular}{ll}
\hline Kondisi & Tidak ada Laporan Penerimaan Barang. \\
\hline Kriteria & $\begin{array}{l}\text { Dalam transaksi retur penjualan, Laporan Penerimaan barang merupakan dokumen pendukung } \\
\text { yang melampiri Memo Kredit atau dalam kasus ini Bukti Retur. Dokumen ini dikeluarkan oleh } \\
\\
\text { fungsi gudang sebagai laporan telah diterima dan diperiksanya barang yang diterima dari agen. }\end{array}$ \\
\hline Sebab & $\begin{array}{l}\text { Perusahaan menganggap informasi yang tercantum dalam Bukti Retur sudah cukup mewakili } \\
\text { sebagai bukti penerimaan barang. }\end{array}$ \\
\hline Akibat & (1) Apabila terjadi masalah, fungsi gudang akan sulit membuktikan bahwa barang tersebut \\
& $\begin{array}{l}\text { belum diterima karena tidak memiliki bukti tertulis apapun; (2) Gagalnya unsur pengendalian } \\
\text { preventif. }\end{array}$ \\
\hline & $\begin{array}{l}\text { Membuat Laporan Penerimaan Barang sehingga perusahan memiliki bukti tertulis mengenai } \\
\text { barang yang diserahkan oleh agen untuk diretur. Laporan Penerimaan Barang minimal harus } \\
\text { memuat tanggal, nama majalah, edisi majalah, jumlah majalah, batas tanggal retur, kondisi pada } \\
\text { saat diterima, keterangan alasan retur dan keterangan diterima atau ditolaknya retur. Dokumen } \\
\text { ini juga harus ditandatangani oleh pihak yang membuat yaitu fungsi gudang serta pihak yang } \\
\text { menyerahkan barang yaitu agen. }\end{array}$ \\
\hline
\end{tabular}

Tabel 6

Kelemahan pada Dokumen (6)

\begin{tabular}{ll}
\hline Kondisi & Tidak membuat Laporan Keterlambatan Pelunasan Piutang. \\
\hline Kriteria & $\begin{array}{l}\text { Laporan Keterlambatang Pelunasan Piutang digunakan perusahaan untuk mengetahui rata-rata } \\
\text { keterlambatan pelunasan piutang agen sebagai salah satu faktor yang menentukan penilaian } \\
\text { agen. }\end{array}$ \\
\hline Sebab & $\begin{array}{l}\text { (1) Perusahaan menganggap belum membutuhkan laporan tersebut; (2) Belum terdapat } \\
\text { prosedur yang mengatur tentang pentingnya dokumen tersebut. }\end{array}$ \\
\hline Akibat & (1) Kesulitan bagi fungsi kredit dalam menilai kebanyakan agen; (2) Gagalnya unsur \\
\hline
\end{tabular}


pengendalian korektif.

Rekomendasi Perusahaan membuat Laporan Keterlambatan Pelunasan Piutang, yang minimal berisi informasi kode agen, nama agen, nomor faktur, tanggal faktur, tanggal jatuh tempo, tanggal pembayaran dan keterlambatan pelunasan piutang.

\section{Evaluasi Terhadap Pengendalian Internal Struktur Organisasi Perusahaan}

Berdasarkan pengamatan yang dilakukan oleh penulis terdapat beberapa kebaikan dalam struktur organisasi perusahaan, antara lain: (1) Fungsi Penjualan terpisah dengan fungsi gudang; (2) Fungsi ipenjualan terpisah dengan fungsi akuntansi; (3) Fungsi penagihan terpisah dari kasir; (4) Fungsi penagihan terpisah dari fungsi akuntansi; (5) Setiap transaksi sudah dilaksanakan oleh lebih dari satu fungsi.

Selain kebaikan-kebaikan di atas, penulis juga menemukan dua kelemahan yang perlu diperhatikan dalam struktur organisasi perusahaan (Tabel 7 dan 8).

Tabel 7

Kelemahan dalam Struktur Organisasi (1)

\begin{tabular}{|c|c|}
\hline Kondisi & $\begin{array}{c}\text { Belum terdapat uraian tugas dan tanggung jawab secara tertulis yang spesifik untuk } \\
\text { masing-masing fungsi. }\end{array}$ \\
\hline Kriteria & $\begin{array}{l}\text { Perusahaan sebaiknya memiliki uraian tugas dan tanggung jawab untuk semua fungsi termasuk } \\
\text { fungsi yang terkait dalam penjualan kredit, retur penjualan dan penerimaan kas secara tertulis } \\
\text { agar setiap fungsi mengetahui jelas batas dari pekerjaan dan tanggung jawabnya. }\end{array}$ \\
\hline Sebab & $\begin{array}{l}\text { Perusahaan menganggap petunjuk pelaksanaan dan standar operasi prosedur untuk masing- } \\
\text { masing departemen sudah cukup sebagai pedoman bagi seluruh karyawan dalam menjalankan } \\
\text { tugas dan tanggung jawab mereka menurut fungsinya. }\end{array}$ \\
\hline Akibat & $\begin{array}{l}\text { (1) Karyawan tidak mengetahui batas pekerjaannya; (2)Para karyawan dikhawatirkan } \\
\text { bekerja tidak proporsional (melaksanakan pekerjaan lebih atau kurang dari batas tanggung } \\
\text { jawabnya); (3) Gagalnya pengendalian preventif. }\end{array}$ \\
\hline Rekomendasi & $\begin{array}{l}\text { Membuat catatan tertulis mengenai uraian serta batasan tugas dan tanggung jawab setiap fungsi } \\
\text { dalam struktur organisasi, di samping standar operasi prosedur dan petunjuk pelaksanaan, } \\
\text { sehingga karyawan mengetahui jelas batas dari pekerjaan dan tanggung jawab mereka menurut } \\
\text { fungsinya. }\end{array}$ \\
\hline
\end{tabular}

Tabel 8

Kelemahan dalam Struktur Organisasi (2)

\begin{tabular}{ll}
\hline \multicolumn{1}{c}{ Kondisi } & \multicolumn{1}{c}{ Belum terdapat fungsi kredit untuk menilai kelayakan agen sebelum diberikan kredit. } \\
\hline Kriteria & $\begin{array}{l}\text { Dalam transaksi penjualan kredit, fungsi kredit bertanggung jawab untuk meneliti status kredit } \\
\text { agen dan memberikan otorisasi pemberian kredit kepada agen, serta melakukan penilaian kepada } \\
\text { agen. }\end{array}$ \\
\hline Sebab & $\begin{array}{l}\text { Perusahan menganggap bahwa tugas dan tanggung jawab fungsi kredit masih dapat } \\
\text { dilaksanakan oleh fungsi penagihan. }\end{array}$ \\
\hline Akibat & $\begin{array}{l}\text { (1) Timbulnya tumpang tindih tugas dan tanggung jawab; (2) Gagalnya unsur pengendalian } \\
\text { krektif, dimana fungsi penagihan melakukan pekerjaan di luar tugas dan tanggung jawabnya } \\
\text { yaitu menagih piutang perusahaan; (3) Sistem kontrol terhadap penilaian agen ataupun calon } \\
\text { agen akan menjadi tidak maksimal, karena tidak ada pengujian untuk penilaian agen. }\end{array}$ \\
\hline Rekomendasi & $\begin{array}{l}\text { Perusahaan memiliki fungsi kredit yang terpisah dengan fungsi penagihan, dimana fungsi } \\
\text { penagihan fokus kepada penagihan piutang perusahaan sementara fungsi kredit meneliti status } \\
\text { kredit agen dan melakukan pengujian terhadap kelayakan kredit agen berdasarkan laporan } \\
\text { penilaian agen. }\end{array}$ \\
\hline
\end{tabular}




\section{Sistem Otorisasi}

Umumnya perusahaan telah menerapkan sistem otorisasi yang jelas dalam dokumen-dokumen yang digunakan dengan membubuhkan tanda tangan pada kolom yang telah disediakan dalam formulir sehingga menunjukkan bahwa dokumen yang sudah dibubuhkan tanda tangan telah disetujui oleh fungsi yang berkaitan. Berikut penjelasannya: (1) Penerimaan Order dari agen diotorisasi oleh fungsi penjualan dengan menggunakan formulir Surat Order; (2) Terjadinya Piutang diotorisasi oleh fungsi penjualan dengan membubuhkan tanda tangan pada Faktur Penjualan; (3) Bukti Pengiriman yang dibuat oleh staf diotorisasi dan dikirimkan oleh supervisior; (4) Bukti Retur diotorisasi oleh fungsi gudang dan ditanda tangani oleh agen yang menyerahkan Barang Retur; (5) Bukti Kas Masuk diotorisasi oleh fungsi penagihan, fungsi akuntansi, dan ditanda tangani oleh agen sebagai pembayar serta kasir sebagai pencatat formulir; (6) Penetapan harga jual, syarat penjualan dan potongan penjualan sudah diatus secara tertulis berdasarkan rapat menajemen dan disetujui oleh direktur. Selain kebaikan-kebaikan di atas, penulis juga menemukan kelemahan dalam sistem otorisasi perusahaan yang harus menjadi perhatian, yaitu:

Tabel 9

Kelemahan dalam Sistem Otorisasi

\begin{tabular}{ll}
\hline Kondisi & Fungsi akuntansi tidak membubuhkan tanda tangan pada formulir Bukti Retur. \\
\hline Kriteria & $\begin{array}{l}\text { Pembubuhan tanda tangan pada formulir Buktu Retur oleh fungsi akuntansi digunakan sebagai } \\
\text { bukti bahwa transaksi tersebut telah dicatat oleh fungsi akuntansi sebagai pengurang piutang } \\
\text { agen. }\end{array}$ \\
\hline Sebab & $\begin{array}{l}\text { Pada formulir Bukti Retur perusahan tidak terdapat kolom otorisasi untuk fungsi akuntansi, } \\
\text { hanya terdapat kolom otorisasi untuk agen sebagai pihak yang menyerahkan barang retur dan } \\
\text { fungsi gudang sebagai pihak yang menerima barang retur. }\end{array}$ \\
\hline Akibat & $\begin{array}{l}\text { (1) Luputnya pencatatan retur ; (2) Tidak adanya jaminan bahwa data yang direkam dalam } \\
\text { formulir tersebut telah dicatat oleh fungsi akuntansi dalam kartu piutang dengan tingkat } \\
\text { ketelitian dan keandalan yang tinggi; (3) Tidak menjamin bahwa kartu piutang dapat menjadi } \\
\text { masukan yang dipercaya bagi proses akuntansi selanjutnya; (4) Gagalnya unsur pengendalian } \\
\text { preventif. }\end{array}$ \\
\hline Rekomendasi & $\begin{array}{l}\text { Merevisi format formulir Bukti Retur dengan menambahkan kolom otorisasi untuk fungsi } \\
\text { akuntansi. Dengan adanya sistem otorisasi seperti ini dapat mengurangi resiko luputnya } \\
\text { pencatatan retur penjualan, karena fungsi akuntansi hanya akan menandatangani Bukti Retur } \\
\text { apabila telah dicatat dalam kartu piutang. }\end{array}$ \\
\hline
\end{tabular}

\section{Prosedur Pencatatan}

Berdasarkan pengamatan yang dilakukan oleh penulis, secara umum proses pencatatan transaksi penjualan kredit, retur penjualan dan penerimaan kas perusahaan sudah didasarkan pada dokumen sumber yang dilampiri dengan dokumen pendukung yang lengkap, selain itu pencatatannya pun dilakukan oleh karyawan yang memang diberikan wewenang, hal ini dapat dilihat saat Fungsi akuntansi mencatat terjadinya piutang atas dasar Faktur Penjualan, Rekapitulasi Faktur Penjualan dan Bukti Pengiriman, dan saat mencatat terjadinya pembayaran atau dasar Laporan Penagihan, Bukti Penerimaan Kas, Bukti Setor Bank, Daftar Piutang yang Ditagih dan Rekening Koran Bank.

Selain kebaikan-kebaikan tersebut di atas, penulis juga menemukan adanya kelemahan dalam prosedur pencatatan yang perlu mendapat perhatian (Tabel 10):

Tabel 10

Kelemahan dalam Prosedur Pencatatan

Kondisi Pencatatan berkurangnya piutang karena retur penjualan hanya berdasarkan pada formulir Bukti Retur tanpa didukung dengan Laporan Piutang Jatuh Tempo dan pengisian informasinya tidak 


\begin{tabular}{ll}
\hline & lengkap. \\
\hline Kriteria & Setiap catatan akuntansi harus diisi informasi yang lengkap dan berasal dari dokumen sumber \\
& yang sahih. Kesahihan dokumen sumber dibuktikan dengan dilampirkannya dokumen \\
& pendukung yang lengkap, yang telah diotorisasi oleh pejabat yang berwenang. Pencatatan \\
& terjadinya Retur Penjualan didasarkan atas Memo Kredit dalam hal ini adalah Bukti Rektur dan \\
& Laporan Penerimaan Barang. Dan Laporan Piutang Jatuh Tempo diisi secara lengkap \\
berdasarkan dokumen sumber. & \\
\hline Sebab & Hal ini disebabkan karena perusahaan belum penyelenggaran dokumen Laporan Penerimaan \\
& Barang. Seperti yang dijelaskan sebelumnya, tidak adanya Laporan Penerimaan Barang \\
& dikarenakan perusahaan menganggap informasi yang tercantum dalam Bukti Retur sudah cukup \\
& mewakili sebagai Bukti Penerimaan Barang dan kurangnya pengawasan dalam pengisian \\
& Laporan juga menjadi salah satu penyebab tidak lengkapnya pencatatan Laporan Piutang Jatuh \\
& Tempo. \\
\hline Akibat & (1) Pengendalian internal atas pencatatan berkurangnya piutang menjadi kurang maksimal; (2) \\
& $\begin{array}{l}\text { Gagalnya unsur pengendalian preventif karena tidak terdapat dokumen sah yang dapat } \\
\text { digunakan fungsi akuntansi sebagai dokumen pendukung bahwa memang benar telah terjadi }\end{array}$ \\
& Retur Penjualan dan Barnag retur sudah diterima oleh fungsi gudang; (3) Kesulitan dalam \\
& menelusuri bukti untuk memastikan bahwa benar piutang telah jatuh tempo karena tidak terdapat \\
informasi yang lengkap tentang dokumen sumber (nomor dan tanggal faktur).
\end{tabular}

\section{Praktik yang Sehat}

Pembagian tanggung jawab fungsional dan sistem wewenang serta prosedur pencatatan yang telah ditetapkan tidak akan terlaksana dengan baik jika tidak diciptakan cara-cara untuk menjamin praktik yang sehat dalam pelaksanaannya. Adapun cara-cara tersebut seperti: (1) Perusahaan secara rutin mengirimkan Kartu Hutang per agen setiap bulannya kepada seluruh agen; (2) Secara periodik diadakan rekonsiliasi Kartu Piutang dengan rekening kontrol piutang dalam buku besar; (3) Hasil perhitungan kas direkam dalam berita acara perhitungan kas dan disetorkan penuh ke bank dengan segera; (4) Secara periodik diadakan stock opname atas persediaan majalah yang dilakukan oleh fungsi gudang dan fungsi akuntansi.

\section{PENUTUP}

\section{Simpulan}

Berdasarkan hasil evaluasi sistem akuntansi penjualan kredit, piutang dan penerimaan kas yang dilakukan terhadap PT. Insan Media Pratama, penulis menyimpulkan bahwa terdapat kelemahan dalam sistem yang berjalan di perusahaan, antara lain: (1) Formulir belum bernomor urut tercetak. Hal ini mengakibatkan tidak adanya pengawasan dalam penggunakaan formulir, kesulitan dalam pengidentifikasian dan pencocokan informasi antara dokumen yang saling berhubungan seperti Surat Order dengan Faktur Penjualan, serta kesulitan dalam pengarsipan dan pencarian kembali dokumen tersebut apabila suatu saat dibutuhkan; (2) Terdapat kekurangan dalam beberapa desain formulir yang digunakan, di mana tidak dicantumkannya informasi seperti kode agen, harga satuan, total dan otorisasi yang jelas pada Surat Order, serta informasi penting lainnya pada beberapa formulir. Akibatnya kesulitan dalam mengidentifikasi agen, kesulitan dalam menentukan tanggung jawab atas timbulnya transaksi tersebut dan kesulitan dalam mengidentifikasi dokumen sumber atas pencatatan sebuah transaksi; (3) Tidak terdapat dokumen Surat Jalan, dokumen Bukti Pengeluaran Barang, dokumen Laporan Penerimaan Barang danLaporan Keterlambatan Pelunasan Piutang. Akibatnya pertama, fungsi gudang tidak memiliki bukti tertulis apapun bahwa telah menyerahkan sejumlah 
barang pada fungsi pengiriman. Kedua, fungsi gudang tidak memiliki bukti tertulis apapun bahwa telah menerima sejumlah barang dari agen, sehingga apabila terjadi masalah akan sulit membuktikan bahwa barang tersebut belum diterima. Ketiga, kesulitan dalam mengambil keputusan penilaian agen oleh fungsi kredit; (4) Perusahaan belum memiliki fungsi kredit untuk menilai kelayakan agen sebelum diberikan kredit.

\section{Saran}

Berdasarkan kelemahan yang terdapat dalam sistem akuntansi penjualan kredit, piutang dan penerimaan kas pada PT. Insan Media Pratama, saran perbaikan yang dapat diberikan kepada perusahaan adalah: (1) Perusahaan memodifikasi format formulir dengan menambahkan nomor urut tercetak, sehingga dapat melakukan pengawasan dalam penggunaannya dan untuk menghindari kesalahan dalam pengidentifikasian informasi serta memudahkan pengarsipan dan pencarian kembali saat dokumen dibutuhkan; (2) Perusahaan membuat Surat Jalan untuk memaksimalkan pengendalian terhadap jasa pengiriman, membuat Bukti Pengeluaran Barang untuk memastikan jumlah yang diserahkan adalah sesuai permintaan dan mengontrol jumlah pengeluaran barang dari gudang, membuat Laporan Penerimaan Barang agar perusahaan memiliki bukti tertulis mengenai barang yang diserahkan oleh agen untuk diretur, serta membuat Laporan Keterlambatan Pelunasan Piutang agar dapat membantu fungsi kredit dalam menilai kelayakan agen; (3) Perusahaan memiliki fungsi kredit yang terpisah dengan fungsi penagihan, diamna fungsi penagihan fokus kepada penagihan piutang perusahaan sementara fungsi kredit melakukan penilaian terhadap kelayakan kredit agen berdasarkan Laporan Penilaian Agen.

\section{DAFTAR PUSTAKA}

Bodnar, G.H., \& Hopwood, W.S. Alih Basa oleh Jusuf, A.A. (2000). Sistem Informasi Akuntansi. Jakarta: Penerbit Salemba Empat.

Hall, J.A. (2007). Sistem Informasi Akuntansi, (edisi 4). (D. Foriasari, \& D.A. Kwary, terj.). Jakarta: Penerbit Salemba Empat.

Mulyadi. (2001). Sistem Akuntansi, (edisi 3). Jakarta: Penerbit Salemba Empat.

Reeve, J. M., Warren, C.S., Duchac, J. E., Wahyuni, E.T., Soepriyanto, G., Jusuf, A.A. (2008). Principle of Accounting: Indonesia adaptation. Jakarta: Penerbit Salemba Empat.

Stice, E.K., Stice, J.D., Skousen, K.F. (2010). Intermediate Accounting (17 ${ }^{\text {th }}$ ed.). South-Western, China: Cengage Learning.

Warren, C. S., Reeve, J. M., Fress, P. E. (2005). Pengantar Akuntansi buku 1, (edisi 21). (A. Farahmita, Amanugrahani, \& T. Hendrawan, Jakarta: Penerbit Salemba Empat.

Wibowo \& Arif, A. (2002). Pengantar Akuntansi 1: Ikhtisar Teori dan Soal-soal. Jakarta: Penerbit Salemba Empat. 